\title{
A Model for Service Quality and Customer Loyalty in Banking Industry of Bangladesh
}

\author{
Md. Hafizur Rahman, Md. Rakibul Islam, Farhana Mitu, Mohitul Ameen Ahmed Mustafi
}

\begin{abstract}
Customers of the banks in Bangladesh are highly service sensitive. Thus, the quality of the services provided by the banks to its customers is the key to success. There is also a relationship between service quality and the customer loyalty in banks. Therefore, this study aims at determining the influence of service quality factors such as, assurance, empathy, reliability, responsiveness, and tangibility on customer loyalty in banking sector in Bangladesh. By using structured questionnaire, this study was conducted on 529 customers of 15 private commercial banks of Bangladesh. Convenient sampling method was used for collecting the data for this study. A multivariate analysis technique like Structural Equation Modeling (SEM) was used for analysing the relationships among service quality dimensions, and customer loyalty. Results show that the service quality factors like assurance and reliability positively affect on customer satisfaction in banking sector of Bangladesh. Results also show that the customer satisfaction is also positively related to customer loyalty in the bank. It is suggested that the policymakers of the banking industry of Bangladesh should give importance on service quality factors like assurance, reliability, specially empathy, responsiveness and tangibility for increasing the customer loyalty in their banks.
\end{abstract}

Index Terms - SERVQUAL, Customer Satisfaction, Customer Loyalty, Reliability, Banking Industry, Bangladesh

\section{INTRODUCTION}

The rapid development of the service industries and their growing importance in world economies have shed the light on the issue of quality in service provision, thus making service quality of fundamental importance (Coulthard, 2004; Mahadeo and Durbarry, 2008). Moreover, the unique and complex nature of services, in terms of certain inherited characteristics such as intangibility, heterogeneity, inseparability, perishability, as well as the high involvement nature of the service delivery system/experience itself, have increased the need for better service quality (Arasli et al., 2005; Uzkurt, 2010). The result is that service quality has, during the past few decades, become a major area of attention to practitioners, managers and researchers, owing to its strong impact on business performance, lower costs, customer satisfaction, customer loyalty and profitability (Cronin and Taylor, 1992; Chang and Chen, 1998; Gummeson, 1998; Lasser et al., 2000; More specifically, Yieh et al. (2007) as

Md. Hafizur Rahman, Lecturer, Department of Marketing, Bangabandhu Sheikh Mujibur Rahman Science and Technology University Gopalgonj, Bangladesh, Mobile No.: +8801677664242

Md. Rakibul Islam, Lecturer, Department of Management Studies Bangabandhu Sheikh Mujibur Rahman Science and Technology University Gopalgonj, Bangladesh, Phone/ Mobile No.+801672944141

Farhana Mitu, Senior Lecturer, School of Business, Uttara University, Dhaka, Bangladesh, Mobile No.:+8801912073718

Mohitul Ameen Ahmed Mustafi, Assistant Professor, School of Business, Uttara University, Bangladesh, Phone/ Mobile No.:+8801670334733 well as Pollack (2009) emphasize the importance of studying the relationships, including direct and indirect effects among service quality, customer satisfaction, and customer loyalty.

\section{OBJECTIVE OF THE STUDY}

The main objective of this study is to identify the factors affecting the customers' loyalty in private commercial banking sector of Bangladesh. The specific objectives are as follows.

$>$ To identify the factors concerning the service quality of private commercial banking sector in Bangladesh;

$>$ To provide some suggestions for the improvement of service quality of the private commercial banking sector in Bangladesh.

\section{LITERATURE REVIEW}

Service Quality

Many researchers like (Bitner, 1990; Mey et al., 2008; Ouyung, 2010; Raza et al., 2012; Osman \& Sentosa, 2013) defined that service quality is the willingness of providers to appropriately implement tangibility, responsiveness, reliability, empathy, and assurance in delivering services could lead to higher customer satisfaction in organizations. These findings of those studies have strongly supported by conceptual service quality model which is invented by Parasuraman, Zeithaml and Berry (1985). The application of service quality model showed that the essence of service quality has to maintain and promote the customer satisfaction. This service quality dimensions have discussed below: Tangible

Tangibles refer to physical facilities, tools or equipment used to provide services and staff appearance. The physical facilities such as signs, comfort, accessibility, spaciousness, functionality and cleanness are part of tangible, D'Cunha and Suresh, 2015 said. This factor is a critical service quality dimension to improve quality performance in the service industry ( $\mathrm{Rad}$ et al., 2006). Additionally, this factor is primarily associated with service verities to meet customer expectations (Caruana and Berthon, 2002). Tangibility is the physical evidence of the service, for instance, the appearance of the tools, equipment and physical facilities, used to provide the service.

\section{Reliability}

Reliability involves service consistency and dependability, which refers to the ability to deliver the service dependably and accurately that customers desire (Parasuraman et al., 1985). Providers deliver the service at the right time and honour their promises, especially billing accurately, keeping 
records correctly and delivering the service to the customer at the designated time (Kondasani and Panda, 2015). If service providers keep their promises, then customer satisfaction increases and their confidence in the service provider increases because the provider's performance gradually improves and consistently meet customer expectations ( $\mathrm{Rad}$ et al., 2006).

\section{Responsiveness}

Responsiveness concerns service provider's willingness or readiness to offer a prompt service (Parasuraman et al., 1985). It deals with timeliness, such as providing quick services to the customer, setting-up appointments as soon as possible, immediately sending the transaction slip to the customer so that $\mathrm{s}$ /he does not form the wrong impression and calling the customer quickly (Calisir et al., 2014). If service providers increase their response to customers, then it is likely to have a positive effect on customer satisfaction (Parasuraman et al., 1985).

\section{Assurance}

Assurance refers to employee knowledge, courtesy and the ability to convey trust and confidence. Employees should have the necessary knowledge and skills to provide the best service to their customers. Courtesy means politeness, respect, consideration and friendliness, such as consideration for the customer's/consumer's property. Conveying trust and confidence means trustworthiness, believability and honesty. It involves having the customer's best interests at heart such as contact personnel characteristics (Kitapci et al., 2014).

\section{Empathy}

Empathy refers to caring, knowing customer demands and individualized attention provided to customers. Capacity to understand customer needs refers to the ability to respond to them such as recognizing regular customers and learning their specific requirements (Parasuraman et al., 1985). Provider empathy and customer relationship has a positive influence on customer satisfaction (Fitzpatrick, 1991; Zarei et al., 2012).

\section{Customer Satisfaction}

Actually customer's satisfaction is the customer's evaluation of goods and services in term of whether it is according to the customer's needs and wants or customers dissatisfied with the product services or the dissatisfied with the performance of the products and not according to expectation of customers and sometime customers more satisfied if products performance is beyond with their expectations. (Kotler P. \&., 2012). Service quality has a positive influence on customer satisfaction (Yee et al., 2010). Zaim, Bayyurt, and Zaim (2010) found that tangibility, reliability and empathy are important for customer satisfaction, but Mengi (2009) found that responsiveness and assurance are more important. Siddiqi (2011) examined the applicability of service quality of retail banking industry in Bangladesh and found that service quality is positively correlated with customer satisfaction; empathy had the highest positive correlation with customer satisfaction, followed by assurance and tangibility. On the other hand, Lo, Osman, Ramayah and Rahim (2010) found that empathy and assurance had the highest influence on customer satisfaction in the Malaysian retail banking industry. Arasli, Smadi and Katircioglu (2005) found that reliability had the highest impact on customer satisfaction.

\section{Customer Loyalty}

Customer loyalty is defined as a hybrid between behavioral and attitudinal loyalty with a higher emphasis on the behavioral aspect of customer loyalty (Ballinger and Rubinson 1996; Dick and Basu 1994). Parasuraman et al. (1988) conceptualize service quality as the relative perceptual distance between customer expectations and evaluations of service experiences and service quality using a multi-item scale called the SERVQUAL model. Loyalty is a multi-dimensional construct that includes both positive and negative responses (Zeithaml et al., 1996). Customer loyalty is defined as a deeply held commitment to re-buy or re-patronize a preferred product consistently in the future despite situational influences (Oliver, 1997).

\section{Relationship between Service Quality and Customer Satisfaction}

In sense of marketing literature, Service Quality and Customer Satisfaction have been closely related to them. This two constructs are positive relationship between them (Beerli et al., 2004). The relationship between customer satisfaction and service quality is doubtful. Some researchers have said that service quality is the antecedent of customer satisfaction, while others researchers have said the opposite relationship. According to Parasuraman et al (1988), service quality and customer satisfaction as "service quality is a global judgement, or attitude, relating to the superiority of the service, whereas satisfaction is related to a specific transaction".

Jamal and Naser (2003) said that service quality is the antecedent of customer satisfaction. However, they found that tangibility and customer satisfaction are not important relationship in service environment. This finding is not supported with previous research by Blodgett and Wakefield (1999), but supported by Parasuraman et al (1991). Most of the researchers found that service quality is the antecedent of customer satisfaction (Bedi, 2010; Kassim and Abdullah, 2010; Kumar et al., 2010; Naeem and Saif 2009; Balaji, 2009; Lee and Hwan, 2005; Athanassopoulos and Iliakopoulos, 2003; Parasuraman et al 1988). According to Yee et al (2010) service quality has a positive influence on customer satisfaction.

Hypothesis 1: Reliability has a positive effect on Customer Satisfaction

Hypothesis 2: Empathy has a positive effect on Customer Satisfaction

Hypothesis 3: Tangibility has a positive effect on Customer Satisfaction

Hypothesis 4: Responsiveness has a positive effect on Customer Satisfaction

Hypothesis 5: Assurance has a positive effect on Customer Satisfaction

Relationship between Customer Satisfaction and Customer Loyalty 
Many of the studies have found that there is positive relationship between customer satisfaction and loyalty (Anderson \& Sullivan, 1993; Bolton \& Drew, 1991; Fornell, 1992). Several studies have also empirically validated the link between satisfaction and behavioral intentions such as customer retention and word of mouth in the service sector (Anderson \& Sullivan, 1993; Bansal \& Taylor, 1999; Cronin \& Taylor, 2000). Hart and Johnson (1999) have added that one of the conditions of true customer loyalty is total satisfaction. Hence, the researchers have hypothesized the following:

Hypothesis 6: Customer satisfaction has a positive effect on customer loyalty.

\section{THEORETICAL FRAMEWORK}

The objective of this study is to investigate why service quality is related to customer loyalty via customer satisfaction. In literature, the related studies suggest that the different dimensions of service quality factors in a banking sectors those are assurance, empathy, tangibility, reliability, responsiveness, customer satisfaction and customer loyalty. The theoretical model is presented in figure 1 . We will look at the theoretical model for each of the hypotheses in the subsection.

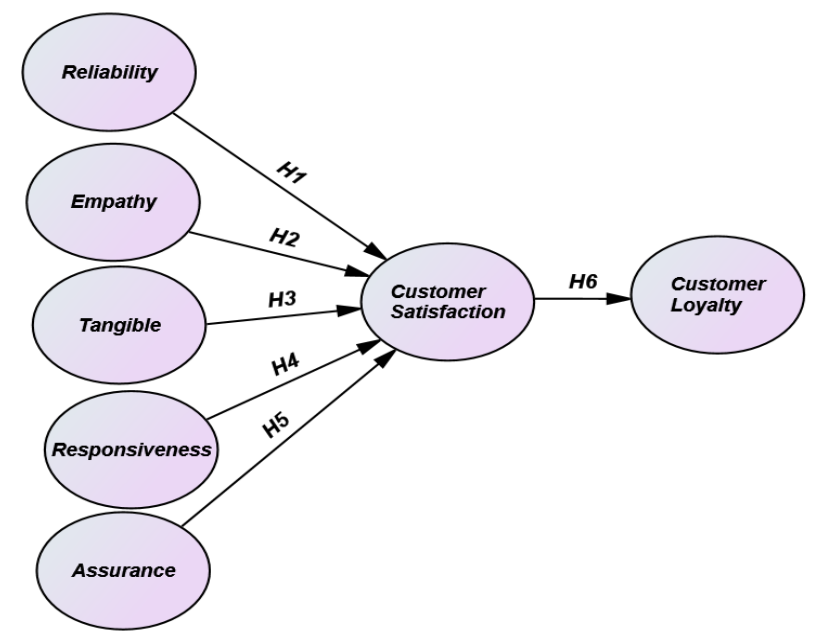

Figure 01: Theoretical Framework of the service quality of Banking Industry of Bangladesh

\section{Methodology}

\section{A. Determination of Sample Size}

This study has been based on both primary and secondary data. To determine the sample size of customer, published formula of University of Florida was used as a reference. According to this formula, the sample size for the more than 10 lac population size with $95 \%$ confidence level and $\pm 5 \%$ precision level are approximately 400 using the following formula Yamane, T (1967):

$$
\mathrm{n}=\frac{N}{\left(1+N e^{2}\right)}
$$

Where, $\mathrm{n}=$ sample size,

$\mathrm{N}=$ the population size, and

$\mathrm{e}=$ the level of precision
Both descriptive and inferential statistics were used to analyze the data. Inferential statistics like Factor Analysis (FA) was used to separate the factors related to service quality of those banks in Bangladesh. Partial Least Square method was also used to identify the significant factors from the factors identified through factor analysis.

\section{Questionnaire Design and Test of Reliability}

This study used both primary and secondary data. We have selected 15 banks from 39 private commercial banks in Bangladesh. This data were collected from the interview of 529 customers from those banks which is located in different places of Dhaka city. A structured questionnaire with 34 items was used to collect the data.

This structured questionnaire with the 5-points scale was developed for the items related to impact of service quality on customer loyalty of private commercial banks in Bangladesh. Five points Likert scale ranging from 1 (strongly disagree) to 5 (strongly agree) was used to collect data from the customers. Four demographic variables, namely, age, gender, and education level, occupation were taken to ensure the variability of different variables. The secondary data were also collected from the journals, website of Bangladesh Bank. Table-2 shows that the reliability coefficient of the questionnaire. It shows that the cronbach's alpha, composite reliability, average variance extracted of the questionnaire are shown table-2 which is at the acceptable limit as per Nunnally and Berstein (1994), Hair et al. 1998, Fornell \& Larcker, (1981); Henseler, Ringle, \& Sinkovics, (2009) respectively.

\section{Data Collection and Analysis}

The sample respondents were selected by using the convenience sampling method. After collecting 550 data, incomplete, biased, and or abnormally answered data were discarded through scrutinizing process and finally 529 data were used in the analysis. The analysis was made by using multivariate analysis techniques such as exploratory factor analysis, confirmatory factor analysis and structural equation modeling.

Table 02: Demographic information of the customers of private commercial banks in Bangladesh

\begin{tabular}{lcc}
\hline & Frequency & Percent \\
\hline Gender & 370 & \\
Male & 159 & 39.9 \\
Female & & \\
Age & 29 & 5.5 \\
Below 20 years & 236 & 44.6 \\
20-30 years & 264 & 49.9 \\
30 years and above & & \\
Education & 148 & 28.0 \\
S.S.C & 152 & 28.7 \\
H.S.C & 137 & 25.9 \\
B.Sc & 92 & 17.4 \\
M.S & & \\
Occupation & 71 & 13.4 \\
Student & 157 & 29.7 \\
Service Holder & 196 & 37.1 \\
Business & 105 & 19.8 \\
House Wife & & \\
\hline
\end{tabular}

From total 529 respondents there are 370 male and 159 
female, whose percentage 69.9 and 30.1 respectively. Considering the age segmentation below 20 years respondents were 29 people, $20-30$ years old 236 people, 30 years and above are 264 people whose percentage 5.5, 44.6 and 49.9 respectively. It shows that the maximum number of respondents is matured person. From the context of educational qualification's criteria SSC passed respondents are 148 , who are 28 percent of total respondents, then HSC passed respondents are 152 person who contains the 28.7 percent then B. Sc passed respondents are 137 person which indicating 25.9 percent thus the M.S passed students are 92 person which contains 17.4 percent.

\section{E. Normality of Data}

According to Tabachnick and Fidell (2001), the value of Skewness and Kurtosis statistic lies between -4 to +4 that is deemed to be acceptable. Table 2 shows that all the data met the acceptable range indicating the normal distribution of data.

Table 03: Normality of the Data in Banking Industry of Bangladesh

\begin{tabular}{|c|c|c|c|}
\hline \multicolumn{4}{|c|}{ Descriptive Statistics } \\
\hline & $\mathrm{N}$ & Skewness & Kurtosis \\
\hline & Statistic & Statistic & Statistic \\
\hline $\begin{array}{l}\text { The behavior of bank's } \\
\text { instill confidence in } \\
\text { customers }\end{array}$ & 529 & -.397 & -1.695 \\
\hline $\begin{array}{l}\text { Customers feel safe in their } \\
\text { transactions with bank's }\end{array}$ & 529 & .170 & -1.840 \\
\hline $\begin{array}{l}\text { Bank's are consistently } \\
\text { courteous with customers }\end{array}$ & 529 & .423 & -1.252 \\
\hline $\begin{array}{l}\text { I find it more convenient to } \\
\text { use technology than } \\
\text { interacting with branch } \\
\text { employees }\end{array}$ & 529 & .641 & -1.122 \\
\hline $\begin{array}{l}\text { My bank's technology } \\
\text { allows me to complete } \\
\text { transactions quickly }\end{array}$ & 529 & .628 & -1.049 \\
\hline $\begin{array}{l}\text { My bank's technology saves } \\
\text { me a lot of time, especially } \\
\text { when I am pressed for time }\end{array}$ & 529 & -.185 & -1.469 \\
\hline $\begin{array}{l}\text { Bank has up to date } \\
\text { equipment (Hardware and } \\
\text { Software) }\end{array}$ & 529 & .415 & -1.359 \\
\hline $\begin{array}{l}\text { Bank's physical facilities } \\
\text { will be visually appealing }\end{array}$ & 529 & .464 & -1.384 \\
\hline $\begin{array}{l}\text { Banks are well dressed and } \\
\text { neat in appearance }\end{array}$ & 529 & .646 & -1.090 \\
\hline $\begin{array}{l}\text { My bank's technology } \\
\text { provides sufficient } \\
\text { information }\end{array}$ & 529 & .262 & -.864 \\
\hline $\begin{array}{l}\text { My bank's technology } \\
\text { provides the reports I need }\end{array}$ & 529 & .332 & -1.438 \\
\hline $\begin{array}{l}\text { My bank's technology gives } \\
\text { me more freedom of } \\
\text { mobility }\end{array}$ & 529 & .219 & -1.286 \\
\hline $\begin{array}{l}\text { Bank's are giving expected } \\
\text { services }\end{array}$ & 529 & .137 & -1.540 \\
\hline
\end{tabular}

\begin{tabular}{|c|c|c|c|}
\hline $\begin{array}{l}\text { Bank's keep promise in } \\
\text { giving services by promised } \\
\text { time }\end{array}$ & 529 & .162 & -1.405 \\
\hline $\begin{array}{l}\text { Bank's show a sincere } \\
\text { interest in solving } \\
\text { customer's problems }\end{array}$ & 529 & .382 & -1.284 \\
\hline Bank's are dependable & 529 & .345 & -1.437 \\
\hline $\begin{array}{l}\text { Bank's provide hassle-free } \\
\text { service to the customers }\end{array}$ & 529 & .504 & -1.096 \\
\hline $\begin{array}{l}\text { I would recommend my } \\
\text { bank to others }\end{array}$ & 529 & .658 & -.950 \\
\hline $\begin{array}{l}\text { I will always consider this } \\
\text { bank as my first choice }\end{array}$ & 529 & .081 & -.776 \\
\hline $\begin{array}{l}\text { I expect to do more business } \\
\text { with my bank in the future }\end{array}$ & 529 & .458 & -1.328 \\
\hline $\begin{array}{l}\text { I believe this bank deserves } \\
\text { my loyalty }\end{array}$ & 529 & .534 & -1.127 \\
\hline $\begin{array}{l}\text { Over the past year, my } \\
\text { loyalty to this bank has } \\
\text { grown stronger }\end{array}$ & 529 & .046 & -1.268 \\
\hline $\begin{array}{l}\text { Bank's insist on error-free } \\
\text { records }\end{array}$ & 529 & .523 & -1.219 \\
\hline $\begin{array}{l}\text { Bank's tell the Customers } \\
\text { truth about the services they } \\
\text { provide }\end{array}$ & 529 & .366 & -1.251 \\
\hline $\begin{array}{l}\text { Bank's maintain } \\
\text { professional ethical } \\
\text { standard }\end{array}$ & 529 & .133 & -.888 \\
\hline $\begin{array}{l}\text { Bank's have the knowledge } \\
\text { to do their job well }\end{array}$ & 529 & .459 & -1.104 \\
\hline $\begin{array}{l}\text { Overall I am satisfied with } \\
\text { my bank }\end{array}$ & 529 & .804 & -.798 \\
\hline $\begin{array}{l}\text { I think I did the right thing } \\
\text { when I chose this bank }\end{array}$ & 529 & -.243 & -1.393 \\
\hline $\begin{array}{l}\text { My bank's services meet my } \\
\text { expectations }\end{array}$ & 529 & .577 & -1.260 \\
\hline I am delighted with my bank & 529 & .506 & -1.318 \\
\hline $\begin{array}{l}\text { Bank's give customers } \\
\text { individual attentions }\end{array}$ & 529 & .784 & -.778 \\
\hline $\begin{array}{l}\text { Bank's have operating } \\
\text { hours convenient to all the } \\
\text { customers }\end{array}$ & 529 & -.091 & -1.475 \\
\hline $\begin{array}{l}\text { Bank's have persons to } \\
\text { listen to provide personal } \\
\text { attentions }\end{array}$ & 529 & .448 & -1.300 \\
\hline $\begin{array}{l}\text { Bank's have customer's best } \\
\text { interests at heart }\end{array}$ & 529 & .303 & -1.438 \\
\hline
\end{tabular}

\section{F. Test of Reliability and Validity}

To analyze the reliability of the data, this study used composite reliability, average variance extracted from the data which are shown in Table -4 is at the acceptable limit as Hair et al. 1998, Fornell \& Larcker, (1981); Henseler, Ringle, \& Sinkovics, (2009) respectively. For checking the discriminant validity, this study followed Fornell Larcker's (1981) criterion that compares AVE Value with corresponding correlation values with other variables. The square-root value of AVE needs to be greater than the corresponding correlation values with other variables (Hair et al., 2014). The Discriminant Validity of the factors is shown in Table 3. 
Table 04: Test of Reliability \& Validity

\begin{tabular}{|l|c|c|c|c|c|}
\hline & $\mathbf{1}$ & $\mathbf{2}$ & $\mathbf{3}$ & $\mathbf{4}$ & $\mathbf{5}$ \\
\hline 1. Tangibility & $\mathbf{0 . 7 3 2}$ & & & & \\
\hline 2. Assurance & 0.550 & $\mathbf{0 . 7 6 3}$ & & & \\
\hline 3. Reliability & 0.342 & 0.516 & $\mathbf{0 . 8 1}$ & & \\
\hline 4. Empathy & 0.446 & 0.379 & 0.28 & $\mathbf{0 . 6 4}$ & \\
\hline 5.Responsiveness & 0.381 & 0.287 & 0.25 & 0.45 & $\mathbf{0 . 7 7 5}$ \\
\hline
\end{tabular}

\section{G. The Coefficient of Determination}

The analysis shows that the $\mathrm{R}$ square value of the model is 0.554 (Table 7). That means, all five independent factors like assurance, empathy, tangibility, reliability, and responsiveness explained $55.4 \%$ of the customer satisfaction of banking sector in Bangladesh.

\section{H. Results and Discussions}

This section describes the results of Exploratory Factor Analysis (EFA), results of Confirmatory Factor Analysis (CFA), and Structural Equation Model (SEM).

\section{Results of Exploratory Factor Analysis (EFA)}

To assess EFA, four commonly used assumptions were followed (Hair et al., 1998; Field, 2000): (i) sampling adequacy (Kaisers - Mayesolkin) measure greater than 0.5; (ii) the minimum eigenvalue for each factor; (iii) considering the sample size, factor loading of 0.50 for each item considered as the threshold for retaining items to ensure greater confidence; and (iv) varimax rotation was used since it is a good general approach that simplifies the interpretations of the factors (Field, 2000).

Table 5 shows the results of exploratory factor analysis. Hair et al. (2010) suggested that factor the analysis can be performed when Kaiser-Meyer-Olkin (KMO) Test and Bartlett's Test of Sphericity are significant. An index of Kaiser's measures of sampling adequacy (Overall MSA= 0.7284) and Bartlett's Test of Sphericity $2 \quad(p=0.000)$ suggested that the factor analysis is appropriate for analyzing the data of this study (Table 5). After examining the pattern matrix of EFA, this study found that all the items had factor loadings greater than 0.50 (Table 5).

This result indicates that the factor analysis is appropriate. After confirming research constructs, principal components analysis and the varimax rotation method were specifically used to extract factors from 34 items. Hair et al. (2010) recommended that each item factors loading must be more than 0.50 values that are considered highly significant. Based on eigen value greater than 1 , a five-factor model was identified that explains $72.84 \%$ of the total variance of the data set. As a whole, 31 items were grouped (based on eigen value) into seven different factors like assurance, empathy, tangibility, reliability, responsiveness, customer satisfaction and customer loyalty by the analysis. The EFA result also showed 0.504 as the lowest and 0.941 as the highest factor loadings of the variables. The result of the factor analysis showed that all the factors, as a whole, are acceptable for further analysis (Table 5).
Table 5: Service quality factors of the customers of the banking industry in Bangladesh

\begin{tabular}{|c|c|c|c|c|}
\hline & EFA & CFA & AVE & CR \\
\hline \multicolumn{5}{|c|}{$\begin{array}{l}\text { Assurance }(\text { Total variance }=8.293, \% \text { of Variance }=37.69 \text {, } \\
\text { Cumulative } \%=37.69)\end{array}$} \\
\hline $\begin{array}{l}\text { The behavior of bank's instill } \\
\text { confidence in customers }\end{array}$ & .709 & 0.77 & \multirow{6}{*}{0.58} & \multirow{6}{*}{0.90} \\
\hline $\begin{array}{l}\text { Customers feel safe in their } \\
\text { transactions with bank's }\end{array}$ & .913 & 0.87 & & \\
\hline $\begin{array}{l}\text { Bank's are consistently } \\
\text { courteous with customers }\end{array}$ & .828 & 0.84 & & \\
\hline $\begin{array}{l}\text { I find it more convenient to } \\
\text { use technology than } \\
\text { interacting with branch } \\
\text { employees }\end{array}$ & .876 & 0.88 & & \\
\hline $\begin{array}{l}\text { My bank's technology allows } \\
\text { me to complete transactions } \\
\text { quickly }\end{array}$ & .870 & 0.79 & & \\
\hline $\begin{array}{l}\text { My bank's technology saves } \\
\text { me a lot of time, especially } \\
\text { when I am pressed for time }\end{array}$ & $\begin{array}{c}0.70 \\
2\end{array}$ & 0.76 & & \\
\hline
\end{tabular}

Tangibility (Total variance $=3.139$, \% of Variance $=14.26$, Cumulative $\%=51.96$ )

Bank has up to date equipment (Hardware and Software)

Bank's physical facilities will be visually appealing

Banks are well dressed and neat in appearance My bank's technology provides sufficient information

My bank's technology provides the reports I need My bank's technology gives me more freedom of mobility

\begin{tabular}{|c|c|}
\hline .504 & $\begin{array}{l}\text { Delete } \\
\mathrm{d}\end{array}$ \\
\hline .895 & 0.85 \\
\hline .800 & 0.77 \\
\hline .751 & 0.80 \\
\hline .875 & 0.78 \\
\hline .892 & 0.80 \\
\hline
\end{tabular}

Reliability (Total variance $=2.187$, \% of Variance $=9.941$, Cumulative \%=61.904)

\begin{tabular}{|c|c|c|c|c|}
\hline $\begin{array}{l}\text { Bank's are giving expected } \\
\text { services }\end{array}$ & .854 & 0.77 & \multirow{5}{*}{$\begin{array}{c}0.66 \\
2\end{array}$} & \multirow{5}{*}{0.92} \\
\hline $\begin{array}{l}\text { Bank's keep promise in } \\
\text { giving services by promised } \\
\text { time }\end{array}$ & .816 & 0.86 & & \\
\hline $\begin{array}{l}\text { Bank's show a sincere } \\
\text { interest in solving customers' } \\
\text { problems }\end{array}$ & .905 & 0.93 & & \\
\hline Bank's are dependable & .916 & 0.95 & & \\
\hline $\begin{array}{l}\text { Bank's provide hassle-free } \\
\text { service to the customers }\end{array}$ & .895 & 0.91 & & \\
\hline \multicolumn{5}{|c|}{$\begin{array}{l}\text { Customer Loyalty }(\text { Total vari } \\
\text { Variance }=7.838, \text { Cumulative } \%=69.74)\end{array}$} \\
\hline $\begin{array}{l}\text { I would recommend my bank } \\
\text { to others }\end{array}$ & .571 & 0.73 & \multirow{5}{*}{$\begin{array}{c}0.71 \\
9\end{array}$} & \multirow{5}{*}{0.91} \\
\hline $\begin{array}{l}\text { I will always consider this } \\
\text { bank as my first choice }\end{array}$ & .825 & 0.88 & & \\
\hline $\begin{array}{l}\text { I expect to do more business } \\
\text { with my bank in the future }\end{array}$ & .892 & 0.90 & & \\
\hline $\begin{array}{l}\text { I believe this bank deserves } \\
\text { my loyalty }\end{array}$ & .879 & 0.75 & & \\
\hline $\begin{array}{l}\text { Over the past year, my } \\
\text { loyalty to this bank has } \\
\text { grown stronger }\end{array}$ & .839 & 0.82 & & \\
\hline
\end{tabular}

Responsiveness (Total variance $=1.376, \%$ of Variance $=6.253$, Cumulative \%=75.99)

\begin{tabular}{|l|c|c|c|c|}
\hline $\begin{array}{l}\text { Bank's insist on error-free } \\
\text { records }\end{array}$ & .823 & 0.80 & 0.60 & 0.86 \\
\cline { 1 - 3 } Bank's tell the Customers & .916 & 0.86 & & \\
\hline
\end{tabular}




\begin{tabular}{|c|c|c|c|c|}
\hline \multicolumn{3}{|l|}{$\begin{array}{l}\text { truth about the services they } \\
\text { provide }\end{array}$} & & \\
\hline $\begin{array}{l}\text { Bank's maintain professional } \\
\text { ethical standard }\end{array}$ & .941 & 0.92 & & \\
\hline $\begin{array}{l}\text { Bank's have the knowledge } \\
\text { to do their job well }\end{array}$ & .890 & 0.85 & & \\
\hline \multicolumn{5}{|c|}{$\begin{array}{lcc}\text { Customer } & \text { Satisfaction } & \text { (Total } \\
\text { Variance }=4.71, \text { Cumulative } \%=69.72)\end{array}$} \\
\hline $\begin{array}{l}\text { Overall I am satisfied with } \\
\text { my bank }\end{array}$ & .807 & 0.75 & \multirow{4}{*}{0.59} & \multirow{4}{*}{0.81} \\
\hline $\begin{array}{l}\text { I think I did the right thing } \\
\text { when I chose this bank }\end{array}$ & .855 & 0.74 & & \\
\hline $\begin{array}{l}\text { My bank's services meet my } \\
\text { expectations }\end{array}$ & .808 & 0.77 & & \\
\hline I am delighted with my bank & .650 & 0.77 & & \\
\hline \multicolumn{5}{|c|}{$\begin{array}{l}\text { Empathy } \quad(\text { Total variance }=1.09, \% \text { of } \text { Variance }=3.12 \text {, } \\
\text { Cumulative } \%=72.84)\end{array}$} \\
\hline $\begin{array}{l}\text { Bank's give customers } \\
\text { individual attentions }\end{array}$ & .782 & 0.72 & \multirow{4}{*}{$\begin{array}{c}0.51 \\
1\end{array}$} & \multirow{4}{*}{0.74} \\
\hline $\begin{array}{l}\text { Bank's have operating hours } \\
\text { convenient to all the } \\
\text { customers }\end{array}$ & .814 & 0.75 & & \\
\hline $\begin{array}{l}\text { Bank's have persons to listen } \\
\text { to provide personal } \\
\text { attentions }\end{array}$ & .823 & 0.71 & & \\
\hline $\begin{array}{l}\text { Bank's have customer's best } \\
\text { interests at heart }\end{array}$ & .730 & 0.69 & & \\
\hline
\end{tabular}

\section{RESULTS OF CONFIRMATORY FACTOR ANALYSIS (CFA)}

CFA was performed to confirm the unidimensionality of the measurement that resulted from the EFA. The relative Chi-Square for this model was 1.529 that was smaller than 5.0 recommended by Marsh and Hocevar (1985). Other fit indexes also showed a good fit for the measurement model. The GFI is of the model is 0.90 which is equal to the recommended value of 0.90 (Joreskog \& Sorbom (1993). Furthermore, the non-incremental fit index, such as the comparative fit index (CFI) is 0.966 that exceeds the recommended cut-off level of 0.90 (Bentler, 1990). Finally, the Root Means Square Error of Approximation (RMSEA) is 0.042 , which is also less than the suggested good fit to the data (Browne \& Cudeck, 1993). The summary result is shown in Table 7 . The fit indices showed good model fit to the data. The other model fit indices are SRMR $=0.044$, and RMR $=0.030$ (Table $7 \&$ Figure 2) .

Table 7: Model Fit Indices and Their Acceptable Thresholds

\begin{tabular}{|c|c|c|c|}
\hline $\begin{array}{c}\text { Goodness of } \\
\text { Fit Indices }\end{array}$ & Value & $\begin{array}{c}\text { Level of } \\
\text { acceptance }\end{array}$ & Reference \\
\hline Chi-square/df & 1.529 & $<5.0$ & $\begin{array}{c}\text { Marsh and Hocevar } \\
(1985)\end{array}$ \\
\hline CFI & .966 & $>0.90$ & Bentler (1990) \\
\hline RMR & 0.03 & $<0.08$ & Hu \& Bentler (1998) \\
\hline GFI & 0.90 & $>0.90$ & $\begin{array}{c}\text { Joreskog \& Sorbom } \\
(1993)\end{array}$ \\
\hline RMSEA & .042 & $<0.08$ & $\begin{array}{c}\text { Browne \& Cudeck } \\
(1993)\end{array}$ \\
\hline SRMR & .044 & $<0.05$ & Hu and Bentler (1999) \\
\hline
\end{tabular}

\section{RESUltS OF StRUCTURAL MODEL (SEM)}

A multivariate analysis technique like covariance-based structural equation modeling was used to identify the significant relationships among service quality dimensions on customer loyalty of private commercial banking sector in Bangladesh and the factors identified through factor analysis like assurance, empathy, tangibility, reliability, and responsiveness. Table 8 lists the structural parameter estimates and hypothesis testing results. This study examines the impact of service quality factors like assurance, empathy, tangibility, reliability, and responsiveness on customer satisfaction as well as customer loyalty in Bangladesh.

The path diagram of this study revealed that only three factors like reliability $(\beta=0.313, p=.000)$, assurance $(\beta$ $=0.128, \quad \mathrm{p}=.003$ ) positively influence the customer satisfaction in banking sector in Bangladesh (Figure 2). But empathy ( $\beta=0.000, p=.991)$, tangibility $(\beta=0.069, p=.138)$, and responsiveness $(\beta=0.047, \mathrm{p}=.193)$ are not significantly related to the customer satisfaction of banking sector in Bangladesh. Hence, the results showed the support for $\mathrm{H} 1$, $\mathrm{H} 5$, and $\mathrm{H} 6$ but not $\mathrm{H} 2$, and $\mathrm{H} 3, \mathrm{H} 4$ in this study.

Table 8: Results of Structural Relationships in Banking Industry of Bangladesh

\begin{tabular}{|c|c|c|c|c|c|}
\hline & Estimate & S.E. & $\begin{array}{l}\mathrm{C} . \\
\mathrm{R}\end{array}$ & $\mathrm{P}$ & $\begin{array}{c}\text { Decision } \\
\mathrm{s}\end{array}$ \\
\hline $\begin{array}{c}\text { Customer } \\
\text { Satisfactio } \\
\mathrm{n}<--- \text { Relia } \\
\text { bility }\end{array}$ & 0.313 & .044 & 7.08 & $* * *$ & Significant \\
\hline $\begin{array}{c}\text { Customer } \\
\text { Satisfactio } \\
n \\
\text { <---Empat } \\
\text { hy }\end{array}$ & 0.000 & .044 & .011 & .991 & $\begin{array}{c}\text { Not } \\
\text { Significant }\end{array}$ \\
\hline $\begin{array}{c}\text { Customer } \\
\text { Satisfactio } \\
n \\
\text { <---Tangib } \\
\text { ility }\end{array}$ & 0.069 & .046 & 1.48 & .138 & $\begin{array}{c}\text { Not } \\
\text { Significant }\end{array}$ \\
\hline $\begin{array}{c}\text { Customer } \\
\text { Satisfactio } \\
\text { n<---Respo } \\
\text { nsiveness }\end{array}$ & 0.047 & .036 & 1.30 & .193 & $\begin{array}{c}\text { Not } \\
\text { Significant }\end{array}$ \\
\hline $\begin{array}{c}\text { Customer } \\
\text { Satisfactio } \\
\mathrm{n}<--- \text { Assur } \\
\text { ance }\end{array}$ & 0.128 & .043 & 2.98 & .003 & Significant \\
\hline $\begin{array}{c}\text { Customer } \\
\text { Loyalty<-- } \\
\text {-Customer } \\
\text { Satisfactio } \\
\text { n }\end{array}$ & 1.157 & .099 & 11.7 & $* * *$ & Significant \\
\hline R-square & & & 0.554 & & \\
\hline
\end{tabular}

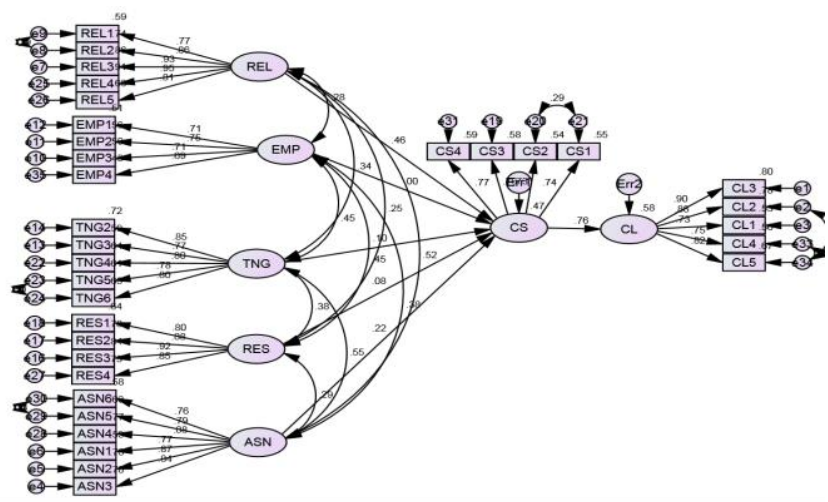

Figure 02: Structural Model of Service Quality Dimension and their relationship among customer satisfaction customer loyalty in private commercial banking sector of Bangladesh 


\section{CONCLUSION}

Structural Equation Model shows that assurance, and reliability have a positively influences on customer satisfaction. Customer satisfaction also influenced on customer loyalty of banking sector in Bangladesh which is support by many research work like Parasuraman et al., 1988, 1991; Zeithaml et al., 1996; Wang et al., 2004). Our finding also shows that some customer's thing there is no tangible change in banking sector, responsibility is not enough for delivering the service of that bank, and the bank employees who have no idea how feel/understand the customers need and making some customers service. For that reason tangibility, responsibility and empathy has no significant effect on customer satisfaction as well as customer loyalty in banking sectors in Bangladesh. It is suggested that the policymakers of the banking industry of Bangladesh should give importance on service quality factors like assurance, reliability, specially empathy, responsiveness and tangibility for increasing the customer loyalty in their banks. However, there is an more than enough scope to identify additional factors by taking more samples and using complex model in consideration by further studies in future.

\section{REFERENCES}

[1] Anderson, E. W., \& Sullivan, M. W. (1993). The antecedents and consequences of customer satisfaction for firms. Marketing science, 12(2), 125-143.

[2] Arasli, H., Mehtap-Smadi, S., \& Turan Katircioglu, S. (2005). Customer service quality in the Greek Cypriot banking industry. Managing Service Quality: An International Journal, 15(1), 41-56.

[3] Athanassopoulos, A. D., \& Iliakopoulos, A. (2003). Modeling customer satisfaction in telecommunications: Assessing the effects of multiple transaction points on the perceived overall performance of the provider. Production and Operations Management, 12(2), 224-245.

[4] Balaji, M. S. (2009). Customer Satisfaction with Indian Mobile Services. IUP Journal of Management Research, 8(10), 52-62.

[5] Baldinger, A. L., \& Rubinson, J. (1996). Brand loyalty: The link between attitude and behavior. Journal of advertising research, 36(6), 22-34.

[6]Bansal,H.S.,Taylor,S.F., 1999.Theserviceproviderswitchingmodel(SPSM ):a model of consumer switching behavior in the services industry. Journal of Service Research 2 (2), 200-218.

[7] Bedi, M. (2010). An Integrated Framework for Service Quality, Customer Satisfaction and Behavioral Responses in Indian Banking Industry--A Comparison of Public and Private Sector Banks. Journal of Services Research, 10(1), 157-172.

[8] Beerli A (2004). A Model of Customer Loyalty in the Retail Banking Market, Eur. J. Mark. 38(1/2): 253 - 275

[9] Bentler, P. M. (1990). Comparative fit indices in structural mode ls. Psychological Bulletin, 88, 588-606.

[10] Bitner, M.J., Booms, B.H., Tetreault, M.S., 1990. The service encounter: diagnosing favorable and unfavorable incidents. Journal of Marketing 54, 71-84.

[11] Bolton, Ruth N. and James H. Drew. (1991). "A Longitudinal Analysis of the Impact of Service Changes on Customer Attitudes," Joumal of Marketing, 55(January): 1-9

[12] Browne, M. W., \& Cudeck, R. (1993). Alternative ways of assessing model fit. In: K. A. Bollen, \& J. Scott Long (Eds.), Testing structural equation models (pp. 136-162). Newbury Park, CA: Sage

[13] Calisir, F., Altin Gumussoy, C., Bayraktaroglu, A. E., \& Karaali, D. (2014). Predicting the intention to use a web-based learning system: Perceived content quality, anxiety, perceived system quality, image, and the technology acceptance model. Human Factors and Ergonomics in Manufacturing \& Service Industries, 24(5), 515-531.

[14] Caruana, A., Money, A. H., \& Berthon, P. R. (2002). Service quality and satisfcation--the moderating role of value. Measuring Business Excellence, 6(1), 45-45.

[15] Chang, T. Z., \& Chen, S. J. (1998). Market orientation, service quality and business profitability: a conceptual model and empirical evidence. Journal of services marketing, 12(4), 246-264.
[16] Coulthard,L.J. M.(2004).Measuring service quality-A review and critique of research using SERVQUAL. International Journal of Market Research 46(4),479-497.

[17] Cronin Jr, J. J., \& Taylor, S. A. (1992). Measuring service quality: a reexamination and extension. The journal of marketing, 55-68.

[18] Cronin, J.J., Brady, M.K., Hult, G.T.M., 2000. Assessing the effects of equality, value, and customer satisfaction on consumer behavioral intentions in service envi- ronments. Journal of Retailing 76 (2) 193-218.

[19] D'Cunha, S., \& Suresh, S. (2015). The measurement of service quality in healthcare: a study in a selected hospital. International Journal of Health Sciences and Research, 5(7), 333-345.

[20] Dick, A. S., \& Basu, K. (1994). Customer loyalty: toward an integrated conceptual framework. Journal of the academy of marketing science, 22(2), 99-113

[21] F. Hair Jr, J., Sarstedt, M., Hopkins, L., \& G. Kuppelwieser, V. (2014). Partial least squares structural equation modeling (PLS-SEM) An emerging tool in business research. European Business Review, 26(2), 106-121.

[22] Field, A. (2000). Discovering statistics using SPSS for Windows: Advanced techniques for beginners (Introducing Statistical Methods series).

[23] Fitzpatrick, R. (1991). Surveys of patients' satisfaction: I--Important general considerations. BMJ: British Medical Journal, 302(6781), 887-889.

[24] Fornell, C. (1992). A national customer satisfaction barometer: The Swedish experience. The Journal of Marketing, 6-21.

[25] Fornell, C., \& Larcker, D. F. (1981). Structural equation models with unobservable variables and measurement error: Algebra and statistics. Journal of marketing research, 382-388.

[26] Gummesson, E. (1998). Productivity, quality and relationship marketing in service operations. International journal of contemporary hospitality management, 10(1), 4-15.

[27] Hair, J. F., Black, W. C., Babin, B. J., Anderson, R. E., \& Tatham, R L. (1998). Multivariate data analysis, 5 (3), 207-219. Upper Saddle River, NJ: Prentice hall.

[28] Hair, J. F., Ringle, C. M., \& Sarstedt, M. (2011). PLS-SEM: Indeed a silver bullet. Journal of Marketing theory and Practice, 19(2), 139-152.

[29] Hart, C. W. \& Johnson, M. D. (1999). Growing the trust relationship. Marketing Management, 14 (Spring), 8-19.

[30] Henseler, J., Ringle, C. M., \& Sinkovics, R. R. (2009). The use of partial least squares path modeling in international marketing. In New challenges to international marketing (pp. 277-319). Emerald Group Publishing Limited.

[31] Hu, L. T., \& Bentler, P. M. (1998). Fit indices in covariance structure modeling: Sensitivity to underparameterized model misspecification. Psychological Methods, 3(4), 424-453.

[32] Hu, L. T., \& Bentler, P. M. (1999). Cutoff criteria for fit indexes in covariance structure analysis: Conventional criteria versus new alternatives. Structural equation modeling: a multidisciplinary journal, 6(1), 1-55.

[33] Jamal, A., \& Naser, K. (2003). Factors influencing customer satisfaction in the retail banking sector in Pakistan. International Journal of Commerce and Management, 13(2), 29-53.

[34] Jöreskog, K. G. (1993). Testing structural equation models. Sage focus editions, 154, 294-294.

[35] Kassim, N., \& Asiah Abdullah, N. (2010). The effect of perceived service quality dimensions on customer satisfaction, trust, and loyalty in e-commerce settings: A cross cultural analysis. Asia Pacific Journal of Marketing and Logistics, 22(3), 351-371.

[36] Kheng, L. L., Mahamad, O., Ramayah, T., \& Mosahab, R. (2010). The impact of service quality on customer loyalty: A study of banks in Penang, Malaysia. International journal of marketing studies, 2(2), 57-66.

[37] Kitapci, O., Akdogan, C., \& Dortyol, I. T. (2014). The impact of service quality dimensions on patient satisfaction, repurchase intentions and word-of-mouth communication in the public healthcare industry. Procedia-Social and Behavioral Sciences, 148, 161-169.

[38] Kondasani, R. K. R., \& Panda, R. K. (2015). Customer perceived service quality, satisfaction and loyalty in Indian private healthcare. International journal of health care quality assurance, 28(5), 452-467.

[39] Kotler P, Armstrong G (2012). Principles of Marketing, $14^{\text {th }}$ Edition, New Jersy, USA . Pearson Education Inc.

[40] Kumar, V., Aksoy, L., Donkers, B., Venkatesan, R., Wiesel, T., \& Tillmanns, S. (2010). Undervalued or overvalued customers: capturing total customer engagement value. Journal of service research, 13(3), 297-310. 
[41] Lassar, W. M., Manolis, C., \& Winsor, R. D. (2000). Service quality perspectives and satisfaction in private banking. Journal of services marketing, 14(3), 244-271.

[42] Lee, M. C., \& Hwan, S. (2005). Relationships among service quality, customer satisfaction and profitability in the Taiwanese banking industry. International journal of management, 22(4), 635-650.

[43] Mahadeo, J. D., \& Durbarry, R. (2008). The level of service quality in the mobile telephony sector: the case of Mauritius. International Journal of Services and Operations Management, 4(6), 730-744.

[44] Marsh, H. W., \& Hocevar, D. (1985). Application of Confirmatory Factor Analysis to the Study of Self-concept: First-and Higher Order Factor Models and Their Invariance Across Groups. Psychological Bulletin, 97(3), 562-582.

[45] Mengi, P. (2009). Customer satisfaction with service quality: An empirical study of public and private sector banks. IUP Journal of Management Research, 8(9), 7-17.

[46] Mey, L.P, Akhbar, A.K., \& David Yong, G.F. (2008). Measuring service quality and customer satisfaction in hotels: Malaysian hotels. Quest for Excellent, July-December, 10-19.

[47] Mohammad Mosadegh Rad, A. (2006). The impact of organizational culture on the successful implementation of total quality management. the TQM Magazine, 18(6), 606-625.

[48] Naeem, H., \& Saif, M. I. (2010). Employee empowerment and customer satisfaction: Empirical evidence from the banking sector of Pakistan. African Journal of Business Management, 4(10), 2028-2031.

[49] Nunally, J.C., \& Bernstein, I.H. (1994). Psychometric Theory. New York: McGraw-Hill

[50] Oliver, R. L., Rust, R. T., \& Varki, S. (1997). Customer delight: foundations, findings, and managerial insight. Journal of retailing, 73(3), 311-336.

[51] Osman, Z., \& Sentosa, I. (2013). Mediating Effect of Customer Satisfaction on Service Quality and Customer Loyalty Relationship in Malaysia Rural Tourism. International Journal of Economics Business and Management Studies, 2(1), 25-37.

[52] Ouyung, Y. (2010). A relationship between the financial consultant's service quality and customer trust after financial tsunami. International Research Journal of Finance and Economics, Issue 36, 76-86.

[53] Parasuraman, A., Berry, L. L., \& Zeithaml, V. A. (1991). Refinement and reassessment of the SERVQUAL scale. Journal of Retailing, 67(4), 420-451.

[54] Parasuraman, A., Zeithaml, V. A., \& Berry, L. L. (1985). A conceptual model of service quality and its implications for future research. the Journal of Marketing, 41-50.

[55] Parasuraman, A., Zeithaml, V. A., \& Berry, L. L. (1985). A conceptual model of service quality and its implication for future research. Journal of Marketing, 49, 41-50.

[56] Parasuraman, A., Zeithaml, V. A., \& Berry, L. L. (1988). SERVQUAL: a multiple-item scale for measuring consumer perceptions of service quality. Journal of Retailing, 64(1), 12-40.

[57] Rad, A. M. M. \& Yarmohammadian, M. H. (2006). A study of relationship between managers' leadership style and employees' job satisfaction. Leadership in Health Services, 19(2), 11-28.

[58] Raza, M. A., Siddiquei, A. N., Awan, H. M., \& Bukhari, K. (2012). Relationship between service quality, perceived value, satisfaction and revisit intention in hotel industry. Interdisciplinary journal of contemporary research in business, 4(8), 788-805.

[59] Siddiqi, K. O. (2011). Interrelations between service quality attributes, customer satisfaction and customer loyalty in the retail banking sector in Bangladesh. International Journal of Business and Management, 6(3), 12-36.

[60] Tabachnick, B. G., \& Fidell, L. S. (2001). Principal components and factor analysis. Using multivariate statistics, 4, 582-633.

[61] Wakefield, K. L., \& Blodgett, J. G. (1999). Customer response to intangible and tangible service factors. Psychology \& Marketing, 16(1), 51-68.

[62] Wang, Y., Lo, H. P., \& Yang, Y. (2004). An integrated framework for service quality, customer value, satisfaction: Evidence from China's telecommunication industry. Information systems frontiers, 6(4), $325-340$

[63] Yamane, T. (1967). Elementary Sampling Theory Prentice Inc. Englewood Cliffs. NS, USA.

[64] Yee, R. W., Yeung, A. C., \& Cheng, T. E. (2010). An empirical study of employee loyalty, service quality and firm performance in the service industry. International Journal of Production Economics, 124(1), 109-120.

[65] Yieh, K., Chiao, Y. C., \& Chiu, Y. K. (2007). Understanding the antecedents to customer loyalty by applying structural equation modeling. Total quality management $\&$ business excellence, 18(3), 267-284.

[66] Zafer Erdogan, B., \& Uzkurt, C. (2010). Effects of ethnocentric tendency on consumers' perception of product attitudes for foreign and domestic products. Cross Cultural Management: An International Journal, 17(4), 393-406.

[67] Zaim, H., Bayyurt, N., \& Zaim, S. (2010). Service quality and determinants of customer satisfaction in hospitals: Turkish experience. The International Business \& Economics Research Journal, 9(5), 51-58.

[68] Zarei, A., Arab, M., Froushani, A. R., Rashidian, A., \& Tabatabaei, S M. G. (2012). Service quality of private hospitals: The Iranian Patients' perspective. BMC health services research, 12(1), 31.

[69] Zeithaml, V. A., Berry, L. L., \& Parasuraman, A. (1996). The behavioral consequences of service quality. The Journal of Marketing, 31-46.

\section{AUTHOR'S PROFILE}

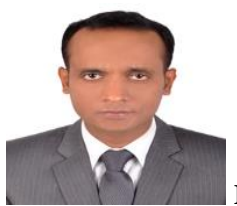

Md. Hafizur Rahman was born in Faridpur; Village-Talma; Post Office -Talma; Thana-Nagarkanda; Bangladesh on 1st January 1985.He received his "Master of Business Administration" and " Bachelor of Business Administration" from Rajshahi University, Bangladesh respectively in 2008 and 2007. At present he is working as a Lecturer of Department of Marketing, Bangabandhu Sheikh Mujibur Rahman Science and Technology University, Gopalgonj.He has published 2 articles in renowned international journals.

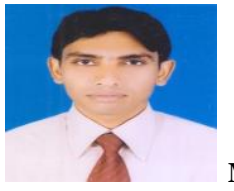

Md. Rakibul Islam was born in Gopalganj Village-Suktail; Post Office - Suktail; Thana- Gopalganj; Bangladesh on 15th September 1986. He received his "Master of Business Administration", and "Bachelor of Business Administration" from Dhaka University, Bangladesh respectively in 2009 and 2008. At present he is working as a Lecturer of Department of Management Studies, Bangabandhu Sheikh Mujibur Rahman Science and Technology University, Gopalgonj.

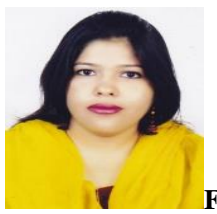
Office - Sukhobuspur; Thana - Munshiganj; District - Dhaka, Bangladesh on 10th September, 1986. She received Master of Business Administration, 2009 from Independent University, Bangladesh, and Bachelor of Business Administration, 2008 East West University, Bangladesh. At present she is working as Senior lecturer of School of Business, Uttara University, Uttara, Dhaka, Bangladesh. She has published more than 4 articles in renowned international journals as well as 01 conferences proceeding in the world.

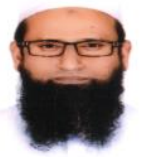

Mohitul Ameen Ahmed Mustafi1 was born in Village - Mongalbaria; Post Office - Pakundia; Thana - Pakundia; District Kishoreganj, Bangladesh on 29th December, 1981. He received Master of Science, 2004 from University of Chittagong and Bachelor of Science, 2003 University of Chittagong, Bangladesh. At present he is working as Assistant Professor of School of Business, Uttara University, Uttara, Dhaka, Bangladesh. He has published more than 23 articles in renowned international journals as well as 13 conferences proceeding in the world. Also he has a member of International Journal of Development and Sustainability (IJDS). His Membership ID is M1500583. 